\title{
Influence of embryonic and maternal genotype on gestational events in the mouse
}

\author{
M. S. Barkley and R. FitzGerald* \\ Department of Animal Physiology, University of California, Davis, California 95616, USA
}

\begin{abstract}
Summary. Mice with high and low prenatal survival were used to study the influence of maternal and embryonic genotype on the timing of implantation, conceptus growth and gestation length. Mice selected for large litter size (Line S1) or rapid post-weaning weight gain (Line G) showed implantation was delayed and gestation prolonged in mice with low prenatal survival (Line G). Reciprocal transfer of Line-S1 and -G embryos to pseudopregnant recipients indicated that conceptus growth was influenced by maternal as well as embryonic genes, at least until mid-pregnancy. In contrast, fetal genotype had a major effect on the length of gestation.
\end{abstract}

Keywords: genotype; implantation; embryo size; gestation; mouse

\section{Introduction}

The gestational process is directed by an interplay between maternal, paternal and fetal genotypes as influenced by a highly variable and sometimes adverse environment. The specific role of each genotype in the determination of intrauterine survival is open to question. In the case of lethal genes affecting the embryo or fetus, the genotype of the young is most influential, but such genes are kept at a very low frequency by natural selection. The genotype of the mother seems to be the more important source of quantitative genetic variation in prenatal survival and litter size (Bradford, 1979). This may be the case in the mouse because the paternal rather than maternal genome influences development of extraembryonic tissues (Barton et al., 1984; Surani, 1985).

The time of first cleavage of ova from natural matings is also influenced by parental genotype (McLaren \& Bowman, 1973). Both the paternal (Shire \& Whitten, 1980a) and maternal (Shire \& Whitten, 1980b) genotype have an effect on this event. The time of first cleavage and the rate of preimplantation embryo development may also be influenced by a gene associated with the mouse major histocompatibility complex (MHC) designated the preimplantation-embryo-development (Ped) gene (Goldbard \& Warner, 1982; Goldbard et al., 1982; reviewed by Warner, 1986). The Ped gene, which may be located in the Qa-2 subregion of the mouse MHC (Warner et al., 1987), is expressed at the time of first cleavage division and seems to have two functional alleles, fast and slow, the fast allele being dominant with no apparent maternal effects on gene expression (Warner, 1986).

In strains of mice that differ in embryo survival, maternal rather than embryonic genotype has a greater influence on intrauterine survival even though embryos of the strain with higher prenatal mortality develop into blastocysts at a slower rate (Moler et al., 1981). This suggested to us that the events surrounding implantation are dynamic and subject to genotypic influence and that other gestational events are affected by the genetic background of the dam. Since the reproductive rate in polytocous species depends on ovulation rate and the proportion of ova that develop into live young, we chose to study mice in which ovulation rate is similar (Lines S1 and G), but embryo survival is substantially different. The time of implantation and gestation length were compared in

*Present address: American Bionetics, Hayward, CA 94545, USA. 
these two lines ( $\mathrm{S} I$ and $\mathrm{G}$ ), and reciprocal embryo transfer was performed to examine the relative influence of maternal and embryonic genes on conceptus growth and survival to term.

\section{Materials and Methods}

Animals. The mice used in this study consisted of two selected strains ( $\mathrm{S} 1$ and $\mathrm{G}$ ) derived from the same base population produced by crossing 4 inbred lines (C57BL/6, AKR, C3H and DBA/2). Lines S1 and G were selected for large litter size and rapid postweaning weight gain, respectively. A randomly bred control line $(\mathrm{C})$ was maintained throughout the selection of lines S1 and G. Descriptions of the development and summaries of the performance of these lines have been reported (Bradford, 1968, 1971). Compared to the randomly bred control line (C), both lines have responded to selection with an increased ovulation rate (Line $C=10 \cdot 3 \pm 0 \cdot 3 ;$ Line $S 1=17 \cdot 6 \pm 0 \cdot 5 ;$ Line $G=$ $17.8 \pm 1.5$ ) (Spearow \& Bradford, 1983). Although more ova are available for fertilization in Lines S1 and G, only mice in Line SI have a larger number of young born because embryo mortality is nearly $50 \%$ in Line $\mathrm{G}$ animals. Mice in Lines $S 1$ and $\mathrm{G}$ also differ in maternal progesterone production throughout pregnancy, with progesterone concentrations in Line S1 mice being 20-60 ng/ml higher than in Line G animals (Barkley et al., 1979).

Initial studies with Line $G$ indicated that its low prenatal survival resulted from both pre- and post-implantational embryo loss. Starting with an ovulation rate of $14.4 \pm 0 \cdot 5$, autopsy on Day 16 of pregnancy revealed an implantation rate of $[1.4 \pm 0.7$, but the number of young born was only $8.5 \pm 0.6$ (Bradford, 1971). Informal observations suggested that the post-implantation loss occurred during the period immediately before and including the transition from maternal to fetal-placental regulation of progesterone production, i.e. Days 8-10. As a result, we chose this period to study post-implantational interactions between maternal and embryonic genotypes and embryo survival.

Animals of both lines were housed in the same animal room maintained at $21-23^{\circ} \mathrm{C}$ and illuminated $14 \mathrm{~h} /$ day (lights on 05:00-19:00 h). Purina Rodent Chow $(\$ 5001)$ and water were supplied ad libitum. Virgin females of approximately 8 weeks of age were placed $3 /$ cage with one male of their own line. Females were checked daily for the presence of a copulatory plug (Day 1 of pregnancy). After a plug was detected, the mated female was housed individually or with other females of the same line that had mated during the same period. Access to the animal room was limited to those individuals directly involved in the project.

Implantation. The time of implantation was determined for mice in Lines $\mathrm{S} 1$ and $\mathrm{G}$ using the method of Orsini \& McLaren (1967). Mated females were housed individually on the day a copulatory plug was found (Day I). For purposes of dating, coitus was assumed to take place at $01: 00 \mathrm{~h}$ on the morning the plug was detected. Beginning on Day 4 at 22:00 h and at hourly intervals thereafter through 08:00 h on Day 5, mated females were randomly selected for study. After anaesthesia, the jugular vein was isolated and $0.1 \mathrm{ml}$ of a $0.5 \%$ solution of pontamine blue was injected (i.v.). After $10 \mathrm{~min}$ the animal was killed by cervical dislocation and the reproductive tract was removed and examined for viable embryos. If no viable embryos were present and if no stain was evident, the animal was excluded from the study.

Embryo transfer. Virgin females approximately 8 weeks of age from Lines S1 and G were used as embryo donors and recipients. Donors were mated to fertile males of the same line, and recipients were mated to vasectomized males. Females were checked daily for copulatory plugs, and the day of plug detection was designated as Day 1 of pregnancy or pseudopregnancy.

The embryo transfer procedure used was similar to that described by Dickmann (1971). Embryos were collected from donors early in the afternoon on Day 4 by excision of the uteri and subsequent flushing with a sterile $3 \%$ solution of bovine serum albumin (BSA: Calbiochem-Behring Corp., San Diego, CA, USA) in phosphate-buffered saline $(0.15 \mathrm{M}, \mathrm{pH} 7 \cdot 4)$. After collection in a small glass pipette, embryos were surgically transferred to a 2.5 -day recipient female. Recipients received 5-10 embryos per uterine horn. Pregnancy rates averaged $40 \%$ for all transfer groups. Animals subjected to sham-transfer were anaesthetized and fluid alone was injected into the uterus.

Gestation length. Inseminated females of Lines S1 and G were randomly assigned to receive sham-surgery or to serve as donors or recipients of embryos. Recipient or sham-operated animals were allowed to deliver young spontaneously. Gestation length was calculated as the period from Day 1 for sham-operated or recipient females to the day of parturition.

Conceptus number and size. Inseminated females of Lines SI and G were randomly assigned to receive shamsurgery or to serve as donors or recipients of asynchronously transferred embryos. Animals subjected to sham-surgery or embryo transfer were killed by rapid decapitation between 10:00 and 12:00 h on Days 9-11 of gestation. The reproductive tract was removed immediately and examined under a dissecting microscope. The number and size of implantation sites were recorded. The latter was determined with the use of a micrometer according to the procedure described previously which includes measurement of implantation site diameter and length from embryonic to abembryonic pole (Barkley, 1982). Animals in which distinct implantation sites could not be detected were excluded from the study.

Data analysis. Analysis of variance was followed by Duncan's New Multiple Range Test to evaluate strain differences or treatment effects. When appropriate, Student's $t$ test was used. Only differences between means at $P<0.05$ at least were considered significant. 


\section{Results}

\section{Time of implantation}

The percentage of Line $\mathrm{S} I$ or $\mathrm{G}$ females with a pontamine blue reaction during each hour of study is shown in Fig. 1. A considerable number (59\%) of Line S1 females had positive implantation sites by $24: 00 \mathrm{~h}$ of Day 4 as compared to Line $\mathrm{G}$ in which implantation had occurred in only $4 \%$ of the animals examined at this time. Another notable difference between the strains was the biphasic pattern of positive pontamine blue reaction in Line $G$. The highest frequency of implantation in this strain occurred between 05:00 and 06:00 h on the morning of Day 5. As indicated in Fig. 1, implantation took place approximately $6 \mathrm{~h}$ earlier in Line $\mathrm{S} 1$ than in Line $\mathrm{G}$ mice.

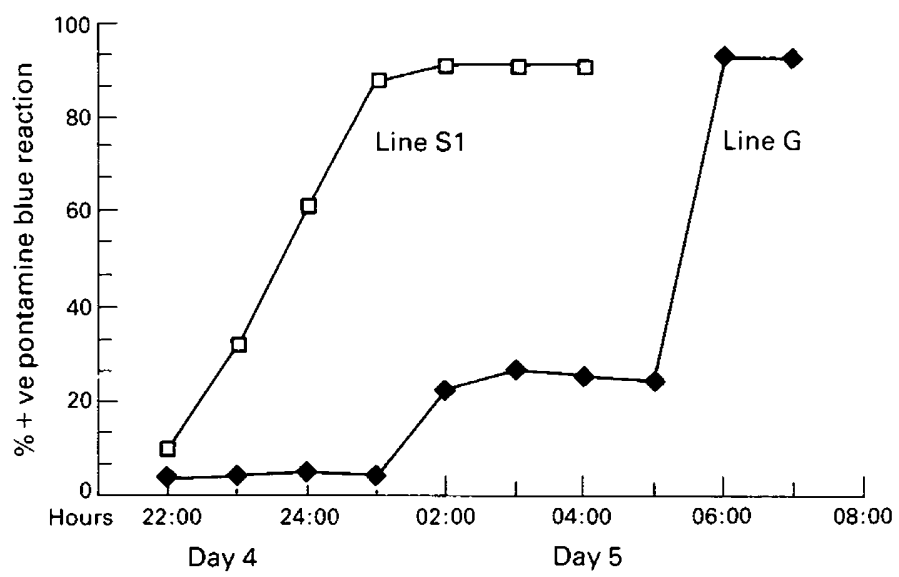

Fig. 1. Positive implantation sites in mice, detected by the pontamine blue reaction plotted against time. Each point represents the mean of 5-10 animals.

As expected, the rate of implantation was higher in Line S1 (14.1 $\pm 0 \cdot 5)$ than in Line G $(10 \cdot 3 \pm 0.8)$, i.e. Line $\mathrm{G}$ mice suffered more preimplantational embryo loss. However, this was not the case for animals which implanted early as shown in Table 1. When the rate of implantation was compared during the period when $<80 \%$ of the females had implanted at any of the times sampled, no strain differences in the number of implantation sites were found. Embryo survival in Line $G$ was significantly $(P \leqslant 0.05)$ decreased when implantation rate was determined after the period when $>80 \%$ of S1 and G females showed evidence of implantation, i.e. after 24:00 h on Day 4 in Line $\mathrm{S} 1$ or after $05: 00 \mathrm{~h}$ on Day 5 in Line G. In general, implantation rate was more stable in Line S1 animals.

Table 1. Time and rate of implantation in mice

\begin{tabular}{lllc}
\hline $\begin{array}{l}\text { Pontamine blue } \\
\text { reaction }\end{array}$ & No. & Time of implantation & $\begin{array}{c}\text { Implantation } \\
\text { rate }\end{array}$ \\
\hline $\begin{array}{l}\text { < } 8 \% \text { positive } \\
\text { Line S1 }\end{array}$ & 19 & $22: 00-24: 00 \mathrm{~h}$, Day 4 & \\
$\quad$ Line G & 56 & $22: 00 \mathrm{~h}$, Day 4-05:00 h, Day 5 & $13 \cdot 5 \pm 0 \cdot 6$ \\
$>80 \%$ positive & & & \\
$\quad$ Line S & 32 & $01: 00 \mathrm{~h}$, Day $5-05: 00 \mathrm{~h}$, Day 5 & $14 \cdot 3 \pm 0 \cdot 7$ \\
Line G & 16 & $06: 00-07: 00 \mathrm{~h}$, Day 5 & $9 \cdot 5 \pm 0 \cdot 9^{*}$ \\
\hline
\end{tabular}

Values are mean \pm s.e.m.

*Significantly different from all other treatment groups $(P \leqslant 0 \cdot 05)$. 


\section{Gestation length after embryo transfer}

Figure 2 shows the gestation length in sham-operated females of Lines $S 1$ and $G$ and after reciprocal embryo transfer. Gestation length was significantly $(P \leqslant 0.05)$ shorter in Line $\mathrm{S} 1$ females $(19.08 \pm 0.18$ days) than in Line $\mathrm{G}$ females $(19.7 \pm 0.16$ days). However, mean gestation length in Line $\mathrm{S} I$ was increased by the presence of Line $\mathrm{G}$ embryos $(P \leqslant 0.05)$. Conversely, gestation length in Line $\mathrm{G}$ was shortened by the presence of Line $\mathrm{S} 1$ embryos $(P \leqslant 0.05)$. The number of embryos did not seem to affect gestation length since both reciprocal transfer groups had equivalent numbers of young born and the sham-operated animals had larger, strain-specific litter sizes.

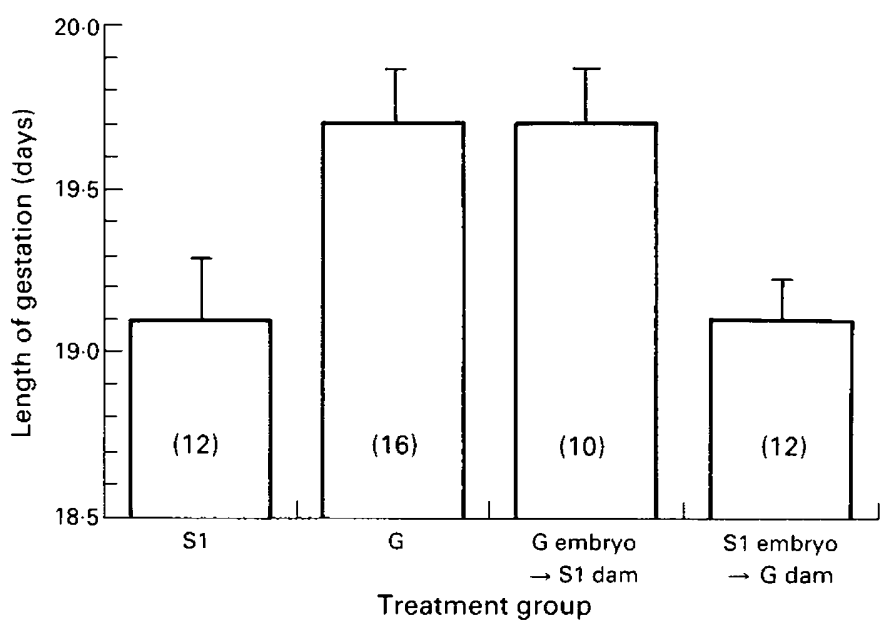

Fig. 2. Mean gestation lengths of sham-operated mice in Lines $S 1$ and $G$, in Line-S1 females receiving Line-G embryos and Line-G females receiving Line-SI embryos. Bars represent the mean \pm s.e.m. for each group. The number of mice in each treatment group is given in parentheses at the base of each bar.

\section{Conceptus number}

The average number of conceptuses in each of the two selected lines ( $\mathrm{S} 1$ and $\mathrm{G}$ ) is given in Table 2. With the exception of Line G (Day 10), all groups in which embryo transfer was performed had a significantly lower number of implantations than any sham-operated group. This effect of embryo transfer on the reduction of implantation number has been observed previously in other strains of mice (Moler et al., 1981). However, the mean number of implantations gradually declined between Days 9 and 11 of gestation, and by Day 11 it resembled the mean litter size following embryo transfer in this and a previous study (Moler et al., 1981). Line S1 mice had significantly $(P \leqslant 0.05)$ more conceptuses than did Line $\mathrm{G}$ mice and any transfer group. On Day 10 of pregnancy, Line S1 females had as many as 19 implantations with an average number of 14 as compared to Line $G$ females which averaged only 7 implantations. Regardless of the strain of recipient or embryo, the number of conceptuses was similar after embryo transfer.

\section{Conceptus size}

The average size of individual conceptuses at autopsy is also given in Table 2. The dimensions of the implantation site reflected both placental mass and fetal tissue. As would be expected, groups in which implantation size was measured on Day 9 of pregnancy differed considerably from groups 
Table 2. Effect of embryo transfer on conceptus number and conceptus size in mice

\begin{tabular}{|c|c|c|c|c|c|}
\hline $\begin{array}{l}\text { Line of } \\
\text { female }\end{array}$ & No. & Treatment & $\begin{array}{c}\text { Day of } \\
\text { pregnancy }\end{array}$ & $\begin{array}{c}\text { No. of } \\
\text { conceptuses }\end{array}$ & $\begin{array}{l}\text { Conceptus } \\
\text { size (mm) }\end{array}$ \\
\hline S! & 7 & Sham-transfer & 9 & $15 \cdot 1 \pm 0 \cdot 9^{a}$ & $0.42 \pm 0.005^{a}$ \\
\hline $\mathrm{G}$ & 7 & Sham-transfer & 9 & $9 \cdot 7 \pm 1.6^{b}$ & $0.42 \pm 0.012^{\mathrm{a}}$ \\
\hline S1 & 8 & Sham-transfer & 10 & $14 \cdot 3 \pm 1 \cdot 1^{\mathrm{a}}$ & $0.41 \pm 0.010^{\mathrm{a}}$ \\
\hline $\mathrm{G}$ & 8 & Sham-transfer & 10 & $7 \cdot 3+1 \cdot 4^{c}$ & $0.43+0.009^{\mathrm{a}}$ \\
\hline S1 & 8 & S1 embryos & 10 & $4 \cdot 0 \pm 0.6^{c}$ & $0.49 \pm 0.014^{b}$ \\
\hline $\mathrm{G}$ & 5 & G embryos & 10 & $4 \cdot 2 \pm 1 \cdot 0^{\mathrm{c}}$ & $0.49 \pm 0.016^{b}$ \\
\hline Sl & 8 & G embryos & 10 & $4.4 \pm 0.9^{c}$ & $0.44 \pm 0.011^{\mathrm{a}}$ \\
\hline G & 8 & S1 embryos & 10 & $4 \cdot 3 \pm 1 \cdot 5^{c}$ & $0.45 \pm 0.010^{\mathrm{a}}$ \\
\hline S1 & 8 & Sham-transfer & 11 & $12 \cdot 8 \pm 1 \cdot 2^{\mathrm{b}}$ & $0.52 \pm 0.017^{b}$ \\
\hline $\mathrm{G}$ & 7 & Sham-transfer & 11 & $8.6 \pm 1.7^{b}$ & $0.50 \pm 0.013^{b}$ \\
\hline
\end{tabular}

Values are mean \pm s.e.m.

Means within the same column not sharing a common superscript are significantly different $(P \leqslant 0.05)$.

measured on Day $11(P \leqslant 0.05)$. Intraline transfer groups ( $\mathrm{G}$ dams with $\mathrm{G}$ embryos and $\mathrm{S} 1 \mathrm{dams}$ with S1 embryos) supported significantly larger embryos on Day 10 than all other groups except for Day 11 sham-operated animals of Lines S1 and G. No between-line differences in implantation size were evident on any of the days $(9,10$ or 11$)$ included in the study.

\section{Discussion}

This is the first report of genetic differences in the timing of implantation in mice derived from a common base population. The earlier implantation in mice with high prenatal survival (Line S1) may be related to the large litter size typical of this strain which also has an increased ovulation rate (Bradford, 1968). Prenatal survival is low in Line $G$ due to both pre- and post-implantation losses (Bradford, 1971). A portion, if not most, of the pre-implantation embryo death in Line G may result from a lack of synchronization between development of the embryo and the uterus which is needed if implantation is to succeed in mice (McLaren \& Michie, 1956; Doyle et al., 1963). For example, a slower rate of early embryo development could result in the observed delay in implantation in Line G. Since genetic differences in the time of ovulation do not play a major role in controlling the time of first cleavage (Shire \& Whitten, 1980b), it is unlikely that variation in time of ovulatory events is responsible for the delay in implantation characteristic of Line $\mathrm{G}$ mice.

Although genetic variation in the tempo of preimplantation embryo development could explain the earlier time of implantation in mice selected for large litter size, it is also possible that differences in an embryo-maternal signal-response mechanism are involved. The mouse uterus is able to distinguish an implanting embryo from an artificial deciduogenic stimulus by reactions of specific proteins (Weitlauf \& Suda-Hartman, 1988). In addition to proteins, other factors including steroids, prostaglandins and histamines have been proposed as messengers in a communication between the uterus and the embryo (reviewed by Heap et al., 1979; Sauer, 1979; Kennedy, 1983). Genetic variation in the production or release of such mediators may also influence timing of pre-implantational events.

The biphasic pattern of implantation times in Line $\mathrm{G}$ is particularly interesting as is the trend toward higher Line-G embryo survival when implantation occurred earlier in this line. Earlier implantation may be related to a more rapid rate of uterine development resulting in greater synchrony with embryo maturation. Regardless of the mechanism(s) involved, embryo size was not affected at the time of mid-gestation. In fact, conceptus size was similar in mice of Lines $G_{2}$ and $S_{2} I_{1}$ 
on Days 9-11 after sham-transfer, suggesting that the rate of fetal growth in Line G compensated for any delay in implantation.

The size on Day 10 of $\mathrm{G}$ and $\mathrm{S} 1$ embryos was also alike following intrauterine development in a host of a different strain. This may be the result of precocious development of Line $\mathrm{G}$ embryos after asynchronous transfer (Doyle et al., 1963). Blastocysts obtained on Day 4 and transferred to Day 3 pseudopregnant recipients undergo a 6-8 h developmental advance before implantation (Marsk, 1977). Transferred embryos in turn implant $6-8 \mathrm{~h}$ earlier than non-transferred blastocysts (Marsk, 1977). Therefore, the time that 3.5-day-old Line G blastocysts waited for endometrial maturity of the recipient uterus may have been sufficient for pre-implantation development to progress to a stage equivalent to that of Line $\mathbf{S 1}$ embryos at the time of implantation. Genetic variation in the timing of implantation could also contribute to the similar conceptus size in Lines G and S1 at midgestation following reciprocal embryo transfer. Indeed, both the maturational stage of the embryo and endometrial maturity are involved in the control of implantation (McLaren, 1968).

Prenatal body size is not simply a function of pre-implantation embryo maturation or the time of implantation. The weight difference between large, small and unselected strains of mice is maintained when blastocysts of each genotype are transferred to unselected control recipients (Aitken et al., 1977). Asynchronous transfer of blastocysts of each genotype results in fetal weights that are higher than those of blastocysts transferred synchronously, genetically smaller mice attaining a greater fetal weight than those of the normal large strain. It was suggested that fetal genotype influences embryonic growth by affecting the state of embryonic development at the time of implantation (Aitken et al., 1977). An extended preimplantation period for asynchronously transferred embryos would result in advanced embryonic development as directed by fetal genotype. However, in certain strains of mice, maternal genotype also influences the rate of fetal growth (El Oksh et al., 1967). The present results suggest that the fetal and maternal genotypes both interact to regulate conceptus size. The increased growth of embryos after transfer to an intra-line uterus (Table 2) supports this idea and is suggestive of a co-adaptive gene complex. This finding is strengthened by the fact that it is independent of fetal number, all recipients of blastocysts implanting approximately the same number of embryos following intra- or inter-line embryo transfer.

Although pre-implantation embryo development and the time of implantation are advanced after asynchronous transfer of mouse blastocysts (Marsk, 1977), pregnancies derived from asynchronously transferred embryos do not terminate earlier (Murrani, 1973). Further evidence that timings of implantational and gestational events are uncoupled is provided by the demonstration that gestation length is shortened by over twice the time gained by an earlier implantation in Line $\mathrm{S} 1$ mice (Fig. 2). A later implantation time in Line $\mathrm{G}$ mice is associated with a longer duration of gestation, but this relationship is independent of the rate of fetal development which seems to have little or no effect on gestation length. What does control the duration of pregnancy? A major effect of fetal genotype on the length of gestation is seen when embryos are transferred to an inter-line, pseudopregnant recipient. Following reciprocal transfer of embryos of Lines $\mathrm{G}$ and $\mathrm{Sl}$ to $\mathrm{S} 1$ and $\mathrm{G}$ dams, the gestation period is consistent with the genotype of the fetus and this effect is independent of the number of gestating embryos. The active role of fetal gene expression in determining the length of gestation in mice has also been found in sheep (Bradford et al., 1972; Kitts et al., 1984), although maternal as well as fetal genotype can influence the duration of pregnancy in the ewe (Anderson et al., 1981).

In summary, the results of this study indicate that the timing of implantation and length of gestation vary with genetic line, but a delayed or advanced implantation is not the only factor that determines conceptus growth. Rather, an interaction between maternal and embryonic genotype infiuences the rate of post-implantation development and survival to term, whereas fetal genotype influences the time when birth takes place.

We thank L. Yokoshima FitzGerald for technical assistance. This work was supported by HD-00394. 


\section{References}

Aitken, R.J., Bowman, P. \& Gauld, I. (1977) The effect of synchronous and asynchronous egg transfer on foetal weight in mice selected for large and small body size. J. Embryol. exp. Morph. 37, 59-64.

Anderson, G.B., Bradford, G.E. \& Cupps, P.T. (1981) Length of gestation in ewes carrying lambs of two different breeds. Theriogenology 16, 119-129.

Barkley, M.S. (1982) The temporal relationship between implantation, termination of prolactin surges, and increased testosterone secretion in the pregnant mouse. Endocrinology 110, 1529-1534.

Barkley, M.S., Geschwind, I.I. \& Bradford, G.E. (1979) The gestational pattern of estradiol, testosterone and progesterone secretion in selected strains of mice. Biol. Reprod. 20, 733-738.

Barton, S.C., Surani, M.A.H. \& Norris, M.L. (1984) Roles of paternal and maternal genomes in mouse development. Nature, Lond. 311, 374-376.

Bradford, G.E. (1968) Selection for litter size in mice in the presence and absence of gonadotropin treatment. Genetics, Princeton 58, 283-295.

Bradford, G.E. (1971) Growth and reproduction in mice selected for body weight gain. Genetics, Princeton 69, $499-512$.

Bradford, G.E. (1979) Genetic variation in prenatal survival and litter size. J. Anim. Sci. 49, 66-74.

Bradford, G.E., Hart, R., Quirke, J.F. \& Land, R.B. (1972) Genetic control of the duration of gestation in sheep. J. Reprod. Fert. 30, 459-463.

Dickmann, Z. (1971) Egg transfer. In Methods in Mammalian Embryology, pp. 133-145. Ed. J. C. Daniel, Jr. WH Freeman and Co., San Francisco.

Doyle, L.L., Gates, A.H. \& Noyes, R.W. (1963) Asynchronous transfer of mouse ova. Fert. Steril. 14, 215-225.

El Oksh, H.A., Sutherland, T.M. \& Williams, J.S. (1967) Prenatal and postnatal maternal influence on growth in mice. Genetics, Princeton 57, 79-94.

Goldbard, S.B. \& Warner, C.M. (1982) Genes affect the timing of early mouse embryo development. Biol. Reprod. 27, 419-424.

Goldbard, S.B., Verbanac, K.M. \& Warner, C.M. (1982) Genetic analysis of $\mathrm{H}-2$ linked gene(s) affecting early mouse development. $J$. Immunogenet. 9, 77-82.

Heap, R.B., Flint, A.P. \& Gadsby, J.G. (1979) Role of embryonic signals in the establishment of pregnancy. Br. med. Bull. 35, 129-135.

Kennedy, T.G. (1983) Embryonic signals and the initiation of blastocyst implantation. Aust. J. biol. Sci. 36, $531-543$.

Kitts, D.D., Anderson, G.B., BonDurant, R.H. \& Stabenfeldt, G.H. (1984) Temporal patterns of $\Delta^{4}$ C-21 steroids in coexisting, genetically dissimilar twin lamb fetuses throughout late gestation. Endocrinology 114, 703-711.
Marsk, L. (1977) Developmental precocity after asynchronous egg transfer in mice. J. Embryol. exp. Morph. 39, 129-137.

McLaren, A. (1968) Mechanisms affecting embryo development. In The Mammalian Oviduct, pp. 477-490. Eds E. S. E. Hafez \& R. J. Blandau. University of Chicago Press, Chicago.

McLaren, A. \& Michie, D. (1956) Studies on the transfer of fertilized mouse eggs to uterine-foster mothers. 1. Factors affecting the implantation and survival of native and transferred eggs. J. exp. Biol. 33, 394416.

McLaren, A. \& Bowman, P. (1973) Genetic effects on the timing of early development in the mouse. $J$. Embryol. exp. Morph. 30, 491-498.

Moler, T.L., Donahue, S.E., Anderson, G.B. \& Bradford, G.E. (1981) Effects of maternal and embryonic genotype on prenatal survival in two selected mouse lines. J. Anim. Sci. 51, 300-303.

Murrani, W.K.G. (1973) Genetical study of selection limits in mice. Ph.D. thesis, University of Edinburgh.

Orsini, M.W. \& McLaren, A. (1967) Loss of the zona pellucida in mice, and the effect of tubal ligation and ovariectomy. J. Reprod. Fert. 13, 485-499.

Sauer, M.J. (1979) Hormone involvement in the establishment of pregnancy. J. Reprod. Fert. 56, 725-743.

Shire, J.G.M. \& Whitten, W.K. (1980a) Genetic variation in the timing of first cleavage in mice: effect of paternal genotype. Biol. Reprod. 23, 363-368.

Shire, J.G.M. \& Whitten, W.K. (1980b) Genetic variation in the timing of first cleavage in mice: effect of maternal genotype. Biol. Reprod. 23, 369-376.

Spearow J.L. \& Bradford, G.E. (1983) Genetic variation in spontaneous ovulation rate and $\mathrm{LH}$ receptor induction in mice. J. Reprod. Fert. 69, 529-537.

Surani, M.A.H. (1985) Development of reconstituted mouse eggs and embryos provides genetic models for fetal development in the human. In Implantation of the Human Embryo, pp. 179-186. Eds R. G. Edwards, J. M. Purdy \& P. C. Steptoe. Academic Press, New York.

Warner, C.M. (1986) Genetic manipulation of the major histocompatibility complex. J. Anim. Sci. 63, 279-287.

Warner, C.M., Gollnick, S.O. \& Goldbard, S.B. (1987) Linkage of the preimplantation-embryo-development (Ped) gene to the mouse major histocompatibility complex (MHC). Biol. Reprod. 36, 606610.

Weitlauf, H.M. \& Suda-Hartman, M. (1988) Changes in secreted uterine proteins associated with embryo implantation in the mouse. J. Reprod. Fert. 84, 539-549.

Received 18 September 1989 